\title{
Ambiguities in Powder Indexing: the Impact of a Quaternary Lattice Metric Singularity on the Characterization of Mawsonite and Chatkalite
}

\begin{abstract}
Alan D. Mighell
National Institute of Standards and Technology,

Gaithersburg, MD 20899-8520
\end{abstract}

alan.mighell@nist.gov

\author{
A lattice metric singularity occurs when \\ unit cells defining two (or more) lattices \\ yield the identical set of unique calculated \\ $d$-spacings. The minerals Mawsonite and \\ Chatkalite are of especial interest as both \\ are characterized by tetragonal unit cells \\ that correspond to the second member of a \\ quaternary lattice metric singularity. This \\ singularity includes lattices that are Cubic \\ $I$, Tetragonal $P$, Orthorhombic $F$, and \\ Orthorhombic $P$. The Mawsonite and \\ Chatkalite lattices are unique in that they \\ are highly specialized. In each case: (1) \\ the determinative $c / a$ ratio is very near \\ $1 / \sqrt{ } 2,(2)$ the symmetrical scalars of the \\ reduced form $[\boldsymbol{a} \cdot \boldsymbol{a}: \boldsymbol{b} \cdot \boldsymbol{b}: \boldsymbol{c} \cdot \boldsymbol{c}=1: 2: 2]$ \\ have greater specialization than required \\ for the given reduced form type, (3) the \\ tetragonal lattice has derivative lattices of \\ higher symmetry, and (4) the powder pat- \\ tern is highly compressed. Mawsonite and \\ Chatkalite serve as exemplar-type com-
}

pounds. Their tetragonal structure has important implications in structure determination using powder diffraction data. First, any cubic $I$ lattice - established solely on the basis of indexing procedures - may actually be tetragonal or orthorhombic. Second, in establishing the lattice of an unknown, results from powder data indexing require routine confirmation by other techniques (e.g., single crystal, optical, etc.).

Key words: ambiguities in powder indexing; Chatkalite; derivative lattices; $d$-spacings; indexing programs; Mawsonite; quaternary lattice metric singularity; powder indexing; specialized lattices.

Accepted: July 24, 2006

Available online: http://www.nist.gov/jres

\section{Introduction}

Today a wide variety of crystal structures are solved using x-ray or neutron powder diffraction data in conjunction with Rietveld refinement techniques. The sequence of steps in the structure determination including data collection, structure determination and refinement - are often integrated and highly automated.

A critical step in the solution process is the determination of a unit cell that defines the lattice. This is commonly done via analogy with related compounds or with an indexing program such as DICVOL91 [1] or TREOR [2]. Unfortunately, the cell determination process is not entirely straightforward and is sometimes fraught with pitfalls. In certain cases, a unique indexing solution does not exist for mathematical reasons. For example, when a lattice metric singularity (LMS) occurs $[3,4]$, there are two or more cells that will account for the same set of observed $d$-spacings.

Herein a quaternary lattice metric singularity and its impact on the characterization of Mawsonite and Chatkalite will be analyzed. In this case, there are four different lattices with three different symmetries (Table 1 ) that are consistent with the same set of $d$-spacings. This has caused considerable confusion and, over the years, Mawsonite has been reported in a variety of ways including pseudo cubic $I$, Tetragonal $I$, and Tetragonal $P$. 
Volume 111, Number 5, September-October 2006

Journal of Research of the National Institute of Standards and Technology

Table 1. Quaternary lattice metric singularity. The four lattices yield the same set of unique calculated $d$-spacings. For each lattice, the table gives the conventional cell along with the corresponding reduced cell and reduced form ${ }^{\mathrm{a}}$.

\begin{tabular}{|c|c|c|c|c|}
\hline & $\begin{array}{l}\text { Lattice I } \\
\text { Cubic } I\end{array}$ & $\begin{array}{l}\text { Lattice II } \\
\text { Tetragonal } P\end{array}$ & $\begin{array}{l}\text { Lattice III } \\
\text { Orthorhombic } F\end{array}$ & $\begin{array}{l}\text { Lattice IV } \\
\text { Orthorhombic } P\end{array}$ \\
\hline \multicolumn{5}{|c|}{ Conventional Cells } \\
\hline Cell & Cell 1 & Cell 2 & Cell 3 & Cell 4 \\
\hline$a(\AA)^{\mathrm{b}}$ & 10.7400 & 7.5943 & 5.0629 & 3.7972 \\
\hline$b(\AA)$ & 10.7400 & 7.5943 & 10.7400 & 5.3700 \\
\hline$c(\AA)$ & 10.7400 & 5.3700 & 15.1887 & 7.5943 \\
\hline$\alpha\left({ }^{\circ}\right)$ & 90.0 & 90.0 & 90.0 & 90.0 \\
\hline$\beta\left(^{\circ}\right)$ & 90.0 & 90.0 & 90.0 & 90.0 \\
\hline$\gamma\left(\left(^{\circ}\right)\right.$ & 90.0 & 90.0 & 90.0 & 90.0 \\
\hline$V\left(\AA^{3}\right)$ & 1238.83 & 309.71 & 825.89 & 154.86 \\
\hline$a / c$ & 1.0 & $\sqrt{2}$ & $1 / 3$ & $1 / 2$ \\
\hline$b / c$ & 1.0 & $\sqrt{2}$ & $\sqrt{1} / 2$ & $\sqrt{1} / 2$ \\
\hline \multicolumn{5}{|c|}{ Reduced Cells } \\
\hline Cell & $\mathrm{R} 1$ & $\mathrm{R} 2^{\mathrm{c}}$ & $\mathrm{R} 3^{\mathrm{d}}$ & $\mathrm{R} 4^{\mathrm{e}}$ \\
\hline$a(\AA)$ & 9.3011 & 5.3700 & 5.0629 & 3.7972 \\
\hline$b(\AA)$ & 9.3011 & 7.5943 & 5.9368 & 5.3700 \\
\hline$c(\AA)$ & 9.3011 & 7.5943 & 8.0051 & 7.5943 \\
\hline$\alpha\left({ }^{\circ}\right)$ & 109.471 & 90.0 & 82.251 & 90.0 \\
\hline$\beta\left({ }^{\circ}\right)$ & 109.471 & 90.0 & 71.565 & 90.0 \\
\hline$\gamma\left(\left(^{\circ}\right)\right.$ & 109.471 & 90.0 & 64.761 & 90.0 \\
\hline$V\left(\AA^{3}\right)$ & 619.42 & 309.71 & 206.47 & 154.86 \\
\hline \multicolumn{5}{|c|}{ Reduced Forms } \\
\hline Form & RF1 & RF2 & RF3 & RF4 \\
\hline$a \cdot a\left(\AA^{2}\right)$ & 86.511 & 28.837 & 25.633 & 14.419 \\
\hline $\boldsymbol{b} \cdot \boldsymbol{b}\left(\AA^{2}\right)$ & 86.511 & 57.673 & 35.245 & 28.837 \\
\hline$c \cdot c\left(\AA^{2}\right)$ & 86.511 & 57.673 & 64.082 & 57.673 \\
\hline$b \cdot c\left(\AA^{2}\right)$ & -28.837 & 0 & 6.408 & 0 \\
\hline $\boldsymbol{a} \cdot \boldsymbol{c}\left(\AA^{2}\right)$ & -28.837 & 0 & 12.816 & 0 \\
\hline $\boldsymbol{a} \cdot \boldsymbol{b}\left(\AA^{2}\right)$ & -28.837 & 0 & 12.816 & 0 \\
\hline \multicolumn{5}{|c|}{ Normalized Reduced Forms } \\
\hline Form & $\mathrm{F} 1$ & $\mathrm{~F} 2$ & F3 & $\mathrm{F} 4$ \\
\hline$a \cdot a$ & 1 & 1 & 1 & 1 \\
\hline$b \cdot b$ & 1 & 2 & 1.375 & 2 \\
\hline$c \cdot c$ & 1 & 2 & 2.500 & 4 \\
\hline$b \cdot c$ & $-1 / 3$ & 0 & $1 / 4$ & 0 \\
\hline$a \cdot c$ & $-1 / 3$ & 0 & $1 / 2$ & 0 \\
\hline$a \cdot b$ & $-1 / 3$ & 0 & $1 / 2$ & 0 \\
\hline $\begin{array}{l}\text { Reduced } \\
\text { Form\# }[5]\end{array}$ & 5 & 21 & 26 & 32 \\
\hline
\end{tabular}

${ }^{a}$ NIST*LATTICE [6] was used to determine lattice relationships given in the table and text.

${ }^{\mathrm{b}}$ Note: $1 \AA\left[=0.1 \mathrm{~nm}=10^{-10} \mathrm{~m}\right]$ is the common unit in crystallography.

Transformations

${ }^{\mathrm{c}} \mathrm{R} 2 \quad \rightarrow \mathrm{R} 1 \quad\left[\begin{array}{lllllllll}1 & -1 & 0 /-1 & 0 & 1 / & -1 & 0 & -1\end{array}\right] \Delta=2$

${ }^{\mathrm{d}} \mathrm{R} 3 \rightarrow \mathrm{R} 1 \quad\left[\begin{array}{lllllllll}1 & 1 & 0 & /-2 & 1 & 0 / & 0 & -1 & 1\end{array}\right] \quad \Delta=3$

${ }^{\mathrm{e}} \mathrm{R} 4 \quad \rightarrow \mathrm{R} 1 \quad\left[\begin{array}{llllllllll}0 & -1 & -1 / 2 & 1 & 0 / & 0 & -1 & 1\end{array}\right] \quad \Delta=4$

(where $\Delta=$ the determinate of the given matrix) 
The research on these minerals demonstrates that in certain cases obtaining the unit cell is difficult. Caution must be taken to obtain the correct lattice. For example, when using indexing procedures, there is no inherent reason to assume the correct answer is necessarily the lattice with the highest symmetry. Clearly, in addition to indexing procedures, other methods - e.g., optical, single crystal, etc. — should be routinely employed to establish uniquely the lattice and symmetry.

\section{Mawsonite and Chatkalite: A Quaternary Quandary}

The minerals Mawsonite and Chatkalite serve to illustrate the role that lattice metric singularities play in the characterization of materials via powder indexing procedures. Over the years, Mawsonite (Table 2) has been characterized by a variety of unit cells. As shown in the Table, they include an I-centered cubic cell [7], an $I$-centered tetragonal cell [9] and a primitive tetragonal cell [10].

In the initial reporting of the mineral Mawsonite, Markham et al. [7] noted that the optical data was inconsistent with cubic symmetry so they used the phrase "body centred pseudocubic" in their description of the mineral. Yamanaka et al. [9], using the refinement program of Evans et al. [12], determined a tetragonal $I$ cell with dimensions close to those of the initial cubic I cell. Single-crystal work by Szymański [10] established the crystal structure as tetragonal $P$. As Chatkalite $\left(\mathrm{Fe}^{2+} \mathrm{Sn}_{2}\right.$ replaces $\mathrm{Fe}_{2}{ }^{3+} \mathrm{Sn}^{4+}$ of Mawsonite) is structurally very similar to Mawsonite, its powder pattern is indexed on the basis of a primitive tetragonal unit cell ( $a=7.61(1) \AA$ and $c=5.373(5) \AA)$ [13]. In the latest Fleischer's Glossary of Mineral Species [14], both Mawsonite and Chatkalite are listed as tetragonal.

There is an underlying mathematical reality that links and explains these diverse unit cells. The determinative $c / a$ ratios for the tetragonal $P$ cells for Mawsonite [10] and for Chatkalite [13] are almost equal to $1 / \sqrt{ } 2$. When this condition occurs, the experimentalist is confronted with a quaternary lattice metric singularity. In this case, therefore, there are four different lattices consistent with the same set of $d$-spacings. Thus from powder data alone one cannot uniquely assign the lattice. This is demonstrated in the next section.

\section{The Quaternary Lattice Metric Singularity}

The four lattices involved in the quaternary singularity are given in Table 1 . The lattices I, II, III, and IV are defined by the $I$-centered cell 1 , the primitive cell 2 , the $F$-centered cell 3, and the primitive cell 4, respectively. When one compares the volumes of the reduced cells for lattices I, II, III, and IV, one notes that the cell volumes are in an 1:1/2:1/3:1/4 relationship. In fact, reduced cells 2,3 , and 4 are derivative subcells of cell 1.

The reduced forms for cells 1-4 that define the four lattices are also given in Table 1. As the reduced forms are all different, the four cells clearly define different lattices. The reduced forms [5] 5, 21, 26, and 32 are characteristic of an $I$-centered cubic, a primitive tetragonal, an $F$-centered orthorhombic and a primitive orthorhombic lattice, respectively. Detailed inspection of the $2 \mathrm{nd}$, 3rd, and 4th reduced forms shows that there is more specialization than required for the given reduced form type [5]. For example, in the case of lattice II, the 1:2:2 relationship between the symmetrical dot products - $\boldsymbol{a} \cdot \boldsymbol{a}: \boldsymbol{b} \cdot \boldsymbol{b}: \boldsymbol{c} \cdot \boldsymbol{c}$ - of the reduced form implies a highly specialized lattice.

In Table 3, the unique $d$-spacings for the four lattices are given. The sets of unique interplanar spacings are identical. However, Table 3 shows that the number $(M)$ of $d$-spacings with a given calculated $d$-value can be different for lattices I-IV. Consider a calculated $d$-value equal to $1.4615 \AA$. For this $d$-value, the Table shows that the numbers $(M)$ calculated for lattices I, II, III, and IV are 1, 2, 9, and 3, respectively. For those cases in which the NBS*AIDS83 [15] program calculates more than one (not symmetrically related) $d$-spacing with the same value, the $h k l$ indices for only the first of the group are given in the Table.

For the nonspecialized lattice of tetragonal or orthorhombic symmetry, the program would calculate $M$ discrete $d$-spacings for those cases in which $M>1$ in Table 3. Inspection of $d$-spacing data for lattices II, III, and IV reveals that these four lattices are highly specialized in the sense that the value of $M$ is often greater than 1 . Thus the patterns have far fewer discrete lines than normally possible for the given symmetry. This is shown in Table 4 . In column 4 of this table, the compression ratio is given. This is the ratio of the unique $d$ spacings to the total calculated $d$-spacings. For the orthorhombic $F$ lattice, the compression ratio is 0.359 when the $d$-spacings are calculated out to a $2 \theta$ of $110^{\circ}$ with $\lambda=1.5405 \AA$. 
Volume 111, Number 5, September-October 2006

Journal of Research of the National Institute of Standards and Technology

Table 2. Comparison of reported diffraction data on Mawsonite

\begin{tabular}{|c|c|c|c|c|c|c|c|c|c|c|c|c|c|c|}
\hline \multirow[b]{2}{*}{ No } & \multicolumn{4}{|c|}{$\begin{array}{l}d \text {-spacings }{ }^{\mathrm{a}} \\
\text { Cubic } I\end{array}$} & \multicolumn{2}{|c|}{$\begin{array}{l}\text { Case A }^{b} \\
\text { Markham } \\
\text { et al. [7] }\end{array}$} & \multicolumn{2}{|c|}{$\begin{array}{l}\text { Case }^{c} \\
\text { Ottemann } \\
\text { et al. [8] }\end{array}$} & \multicolumn{2}{|c|}{$\begin{array}{l}\text { Case } C^{\mathrm{d}} \\
\text { Yamanaka } \\
\text { et al. [9] }\end{array}$} & \multicolumn{2}{|c|}{$\begin{array}{l}\text { Case } D^{\mathrm{e}} \\
\text { Szymański } \\
{[10]}\end{array}$} & \multicolumn{2}{|c|}{$\begin{array}{l}\text { Case } E^{f} \\
\text { Kissin } \\
\text { et al. [11] }\end{array}$} \\
\hline & & $h k l$ & & $d$-calc & $d$-obs & $I$ & $d$-obs & $I$ & $d$-obs & $I$ & $d$-calc & $I$ & $d$-obs & $I$ \\
\hline 1 & 1 & 1 & 0 & 7.5943 & & & & & 7.62 & 3 & & & & \\
\hline 2 & 2 & 0 & 0 & 5.3700 & 5.37 & 20 & & & 5.38 & 10 & 5.37 & 11 & 5.3 & 1 \\
\hline 3 & 2 & 1 & 1 & 4.3846 & 4.37 & 20 & & & 4.38 & 15 & 4.38 & 14 & 4.38 & 4 \\
\hline 4 & 2 & 2 & 0 & 3.7972 & 3.80 & 10 & & & 3.80 & 8 & 3.800 & 6 & 3.70 & $1 / 2$ \\
\hline 5 & 3 & 1 & 0 & 3.3963 & 3.34 & 10 & & & 3.378 & 4 & & & & \\
\hline 6 & 2 & 2 & 2 & 3.1004 & 3.09 & 100 & 3.105 & $\mathrm{~m}$ & 3.099 & 100 & 3.100 & 100 & 3.10 & 10 \\
\hline 7 & 3 & 2 & 1 & 2.8704 & 2.875 & 20 & & & 2.868 & 10 & 2.871 & 13 & 2.88 & 4 \\
\hline 8 & 4 & 0 & 0 & 2.6850 & 2.680 & 50 & 2.652 & w & 2.684 & 25 & 2.683 & 26 & 2.69 & 6 \\
\hline 9 & 3 & 3 & 0 & 2.5314 & & & & & 2.462 & 3 & & & 2.52 & 5 \\
\hline 10 & 4 & 2 & 0 & 2.4015 & 2.395 & 10 & & & 2.401 & 8 & 2.401 & 6 & 2.41 & 3 \\
\hline 11 & 3 & 3 & 2 & 2.2898 & 2.287 & 10 & & & 2.291 & 5 & 2.291 & 4 & 2.30 & 2 \\
\hline 12 & 4 & 2 & 2 & 2.1923 & 2.185 & 5 & & & 2.192 & 3 & 2.190 & 2 & 2.19 & 1 \\
\hline 13 & 5 & 1 & 0 & 2.1063 & 2.098 & 5 & & & & & & & 2.09 & $1 / 2$ \\
\hline 14 & 5 & 2 & 1 & 1.9608 & 1.959 & 5 & & & 1.962 & 3 & 1.962 & 3 & 1.958 & $1 / 2$ \\
\hline 15 & 4 & 4 & 0 & 1.8986 & 1.895 & 80 & 1.887 & $\mathrm{~s}$ & 1.899 & 75 & 1.899 & 70 & 1.899 & 7 \\
\hline 16 & 5 & 3 & 0 & 1.8419 & & & & & & & & & & \\
\hline 17 & 6 & 0 & 0 & 1.7900 & 1.788 & 5 & & & 1.791 & 3 & 1.790 & 3 & 1.790 & 2 \\
\hline 18 & 6 & 1 & 1 & 1.7423 & 1.739 & 5 & & & 1.742 & 3 & 1.742 & 3 & 1.741 & 2 \\
\hline 19 & 6 & 2 & 0 & 1.6981 & & & & & & & & & & \\
\hline 20 & 5 & 4 & 1 & 1.6572 & & & & & & & & & & \\
\hline 21 & 6 & 2 & 2 & 1.6191 & 1.618 & 60 & 1.612 & W & 1.620 & 40 & 1.619 & 43 & 1.618 & 6 \\
\hline 22 & 6 & 3 & 1 & 1.5835 & & & & & & & 1.581 & 2 & 1.584 & $1 / 2$ \\
\hline 23 & 4 & 4 & 4 & 1.5502 & 1.547 & 10 & & & 1.549 & 7 & 1.550 & 6 & 1.552 & 3 \\
\hline 24 & 5 & 5 & 0 & 1.5189 & & & & & & & & & & \\
\hline 25 & 6 & 4 & 0 & 1.4894 & & & & & & & & & & \\
\hline 26 & 7 & 2 & 1 & 1.4615 & 1.460 & 5 & & & 1.463 & 3 & 1.462 & 3 & 1.462 & 2 \\
\hline 27 & 6 & 4 & 2 & 1.4352 & & & & & & & & & 1.438 & $1 / 2$ \\
\hline 28 & 7 & 3 & 0 & 1.4102 & & & & & & & & & & \\
\hline 29 & 6 & 5 & 1 & 1.3640 & & & & & 1.366 & 3 & 1.365 & 3 & 1.362 & $1 / 2$ \\
\hline 30 & 8 & 0 & 0 & 1.3425 & 1.343 & 20 & 1.333 & w & 1.344 & 15 & 1.341 & 13 & 1.338 & 5 \\
\hline 31 & 7 & 4 & 1 & 1.3220 & & & & & 1.318 & 3 & & & & \\
\hline 32 & 8 & 2 & 0 & 1.3024 & & & & & 1.302 & 4 & 1.303 & 1 & & \\
\hline 33 & 6 & 5 & 3 & 1.2837 & & & & & & & & & & \\
\hline 34 & 6 & 6 & 0 & 1.2657 & & & & & & & & & & \\
\hline 35 & 7 & 5 & 0 & 1.2485 & & & & & & & & & & \\
\hline 36 & 6 & 6 & 2 & 1.2320 & 1.232 & 30 & 1.228 & $\mathrm{~m}$ & 1.233 & 10 & 1.232 & 20 & & \\
\hline 37 & 7 & 5 & 2 & 1.2161 & & & & & & & & & 1.213 & $1 / 2$ \\
\hline 38 & 8 & 4 & 0 & 1.2008 & 1.201 & 5 & 1.199 & $\mathrm{w}$ & 1.201 & $5 b$ & 1.201 & $9 b$ & 1.201 & 3 \\
\hline 39 & 9 & 1 & 0 & 1.1860 & & & & & & & & & & \\
\hline 40 & 8 & 4 & 2 & 1.1718 & & & & & & & & & & \\
\hline 41 & 9 & 2 & 1 & 1.1581 & & & & & & & & & 1.155 & $1 / 2$ \\
\hline- & - & & & - & & & & & & & & & & \\
\hline 45 & 8 & 4 & 4 & 1.0961 & & 50 & 1.093 & $\mathrm{~m}$ & 1.096 & 15 & 1.096 & 34 & 1.095 & 7 \\
\hline 46 & 7 & 7 & 0 & 1.0849 & & & & & & & & & & \\
\hline 47 & 8 & 6 & 0 & 1.0740 & & & & & & & & & & \\
\hline 48 & 10 & 1 & 1 & 1.0634 & 1.065 & 50 & & & & & & & & \\
\hline 49 & 10 & 2 & 0 & 1.0531 & & & & & & & & & & \\
\hline 50 & 9 & 5 & 0 & 1.0432 & & & & & & & & & & \\
\hline 51 & 10 & 2 & 2 & 1.0335 & 1.034 & 20 & 1.031 & w & & & 1.033 & 22 & 1.032 & 5 \\
\hline 52 & 10 & 3 & 1 & 1.0240 & & & & & & & & & 1.023 & $1 / 2$ \\
\hline 53 & 8 & 7 & 1 & 1.0059 & & & & & & & & & & \\
\hline 54 & 10 & 4 & 0 & 0.9972 & & & & & & & & & 0.9967 & $1 / 2$ \\
\hline- & - & & & - & & & & & & & & & & \\
\hline 58 & 10 & 5 & 1 & 0.9568 & & & & & & & & & 0.9567 & $1 / 2$ \\
\hline 59 & 8 & 8 & 0 & 0.9493 & 0.950 & 20 & & & & & 0.949 & 25 & 0.9491 & 5 \\
\hline- & - & & & - & & & & & & & & & & \\
\hline
\end{tabular}

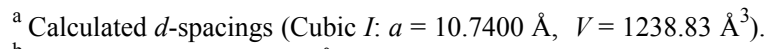

${ }^{\mathrm{b}}$ Cubic $I$ with $a=10.74(1) \AA$ (Mawsonite observed powder data indexed).

${ }^{\mathrm{c}}$ Cubic $I$ with $a=10.710(5) \AA$ (Germanium Mawsonite observed powder data indexed).

${ }^{\mathrm{d}}$ Tetragonal $I$ with $a=10.745(1) \AA$ and $c=10.711(6) \AA$ (Mawsonite observed powder data indexed).

${ }^{\mathrm{e}}$ Tetragonal $P$ with $a=7.603(2) \AA$ and $c=5.358(1) \AA$ (Cell and structure determined by single-crystal x-ray analysis. Powder pattern calculated).

${ }^{\mathrm{f}}$ Tetragonal $P$ with $a=7.603(2) \AA$ and $c=5.358(1) \AA$ (Mawsonite observed powder pattern indexed). 
Volume 111, Number 5, September-October 2006

Journal of Research of the National Institute of Standards and Technology

Table 3. Quaternary lattice metric singularity. For the four lattices, the values of the calculated $d$-spacings $(\AA)$ are identical

\begin{tabular}{|c|c|c|c|c|c|c|c|c|c|c|c|c|}
\hline \multirow[b]{2}{*}{ No } & \multicolumn{2}{|c|}{$\begin{array}{l}\text { Lattice I: } \\
\text { Cubic } I^{\mathrm{a}}\end{array}$} & \multirow[b]{2}{*}{$M^{\mathrm{e}}$} & \multicolumn{3}{|c|}{$\begin{array}{l}\text { Lattice II: } \\
\text { Tetragonal } P^{\mathrm{b}}\end{array}$} & \multicolumn{2}{|c|}{$\begin{array}{l}\text { Lattice III: } \\
\text { Orthorhombic } F^{c}\end{array}$} & \multirow[b]{2}{*}{$M$} & \multicolumn{2}{|c|}{$\begin{array}{l}\text { Lattice IV: } \\
\text { Orthorhombic } P^{\mathrm{d}}\end{array}$} & \multirow[b]{2}{*}{$M$} \\
\hline & $h k l$ & $d$-calc & & $h k 1$ & $d$-calc & $M$ & $h k l$ & $d$-calc & & $h k l$ & $d$-calc & \\
\hline 1 & 110 & 7.5943 & 1 & 100 & 7.5943 & 1 & $\begin{array}{lll}0 & 0 & 2\end{array}$ & 7.5943 & 1 & $\begin{array}{lll}0 & 0 & 1\end{array}$ & 7.5943 & 1 \\
\hline 2 & 200 & 5.3700 & 1 & 110 & 5.3700 & 2 & 020 & 5.3700 & 1 & $\begin{array}{lll}0 & 1 & 0\end{array}$ & 5.3700 & 1 \\
\hline 3 & $\begin{array}{lll}2 & 1 & 1\end{array}$ & 4.3846 & 1 & $\begin{array}{lll}1 & 0 & 1\end{array}$ & 4.3846 & 1 & $\begin{array}{lll}022 & 2\end{array}$ & 4.3846 & 2 & $\begin{array}{llll}0 & 1 & 1\end{array}$ & 4.3846 & 1 \\
\hline 4 & 220 & 3.7972 & 1 & 200 & 3.7972 & 2 & $\begin{array}{lll}0 & 0 & 4\end{array}$ & 3.7972 & 1 & $\begin{array}{lll}0 & 0 & 2\end{array}$ & 3.7972 & 2 \\
\hline 5 & $\begin{array}{lll}3 & 1 & 0\end{array}$ & 3.3963 & 1 & 210 & 3.3963 & 1 & 113 & 3.3963 & 1 & $\begin{array}{lll}1 & 0 & 1\end{array}$ & 3.3963 & 1 \\
\hline 6 & 222 & 3.1004 & 1 & $\begin{array}{lll}2 & 0 & 1\end{array}$ & 3.1004 & 1 & 024 & 3.1004 & 1 & $\begin{array}{lll}0 & 1 & 2\end{array}$ & 3.1004 & 2 \\
\hline 7 & $\begin{array}{lll}3 & 2 & 1\end{array}$ & 2.8704 & 1 & $\begin{array}{lll}2 & 1 & 1\end{array}$ & 2.8704 & 1 & 131 & 2.8704 & 1 & $\begin{array}{lll}11 & 1\end{array}$ & 2.8704 & 1 \\
\hline 8 & 400 & 2.6850 & 1 & 220 & 2.6850 & 2 & 040 & 2.6850 & 1 & $\begin{array}{lll}0 & 2 & 0\end{array}$ & 2.6850 & 2 \\
\hline 9 & 330 & 2.5314 & 1 & $\begin{array}{lll}3 & 0 & 0\end{array}$ & 2.5314 & 2 & 042 & 2.5314 & 5 & $\begin{array}{lll}0 & 0 & 3\end{array}$ & 2.5314 & 2 \\
\hline 10 & 420 & 2.4015 & 1 & $\begin{array}{lll}3 & 1 & 0\end{array}$ & 2.4015 & 3 & 202 & 2.4015 & 1 & 112 & 2.4015 & 1 \\
\hline 11 & 332 & 2.2898 & 1 & $\begin{array}{lll}3 & 0 & 1\end{array}$ & 2.2898 & 1 & 026 & 2.2898 & 2 & $\begin{array}{lll}0 & 1 & 3\end{array}$ & 2.2898 & 1 \\
\hline 12 & 422 & 2.1923 & 1 & $\begin{array}{lll}3 & 1 & 1\end{array}$ & 2.1923 & 2 & 044 & 2.1923 & 2 & 022 & 2.1923 & 2 \\
\hline 13 & $\begin{array}{lll}5 & 1 & 0\end{array}$ & 2.1063 & 1 & 320 & 2.1063 & 2 & 135 & 2.1063 & 2 & 103 & 2.1063 & 2 \\
\hline 14 & $\begin{array}{lll}5 & 2 & 1\end{array}$ & 1.9608 & 1 & $\begin{array}{lll}3 & 2 & 1\end{array}$ & 1.9608 & 1 & 151 & 1.9608 & 3 & 113 & 1.9608 & 1 \\
\hline 15 & 440 & 1.8986 & 1 & $\begin{array}{lll}4 & 0 & 0\end{array}$ & 1.8986 & 2 & $\begin{array}{lll}0 & 0 & 8\end{array}$ & 1.8986 & 1 & $\begin{array}{lll}0 & 0 & 4\end{array}$ & 1.8986 & 3 \\
\hline 16 & 530 & 1.8419 & 1 & $\begin{array}{lll}4 & 1 & 0\end{array}$ & 1.8419 & 2 & 153 & 1.8419 & 3 & 023 & 1.8419 & 2 \\
\hline 17 & 600 & 1.7900 & 1 & 330 & 1.7900 & 4 & 060 & 1.7900 & 4 & $\begin{array}{lll}0 & 14\end{array}$ & 1.7900 & 3 \\
\hline 18 & $\begin{array}{lll}6 & 1 & 1\end{array}$ & 1.7423 & 1 & $\begin{array}{lll}4 & 1 & 1\end{array}$ & 1.7423 & 2 & 062 & 1.7423 & 2 & $\begin{array}{lll}0 & 3 & 1\end{array}$ & 1.7423 & 2 \\
\hline 19 & 620 & 1.6981 & 1 & 420 & 1.6981 & 3 & 226 & 1.6981 & 1 & 104 & 1.6981 & 2 \\
\hline 20 & 541 & 1.6572 & 1 & 322 & 1.6572 & 1 & 155 & 1.6572 & 3 & 123 & 1.6572 & 1 \\
\hline 21 & 622 & 1.6191 & 1 & 421 & 1.6191 & 2 & 064 & 1.6191 & 1 & 032 & 1.6191 & 4 \\
\hline 22 & $\begin{array}{lll}6 & 3 & 1\end{array}$ & 1.5835 & 1 & 213 & 1.5835 & 1 & 119 & 1.5835 & 2 & 131 & 1.5835 & 1 \\
\hline 23 & 444 & 1.5502 & 1 & 402 & 1.5502 & 1 & 048 & 1.5502 & 1 & 024 & 1.5502 & 2 \\
\hline 24 & 550 & 1.5189 & 1 & $\begin{array}{lll}5 & 0 & 0\end{array}$ & 1.5189 & 2 & $\begin{array}{lll}0 & 0 & 10\end{array}$ & 1.5189 & 3 & $\begin{array}{lll}0 & 0 & 5\end{array}$ & 1.5189 & 3 \\
\hline 25 & 640 & 1.4894 & 1 & $\begin{array}{lll}5 & 1 & 0\end{array}$ & 1.4894 & 3 & 246 & 1.4894 & 1 & 132 & 1.4894 & 1 \\
\hline 26 & 721 & 1.4615 & 1 & 431 & 1.4615 & 2 & 171 & 1.4615 & 9 & $\begin{array}{lll}0 & 1 & 5\end{array}$ & 1.4615 & 3 \\
\hline 27 & 642 & 1.4352 & 1 & $\begin{array}{lll}5 & 1 & 1\end{array}$ & 1.4352 & 3 & 262 & 1.4352 & 1 & 124 & 1.4352 & 2 \\
\hline 28 & 730 & 1.4102 & 1 & 520 & 1.4102 & 1 & 173 & 1.4102 & 1 & 105 & 1.4102 & 1 \\
\hline 29 & 651 & 1.3640 & 1 & $\begin{array}{lll}5 & 2 & 1\end{array}$ & 1.3640 & 2 & 264 & 1.3640 & 2 & 115 & 1.3640 & 2 \\
\hline 30 & 800 & 1.3425 & 1 & 440 & 1.3425 & 2 & $\begin{array}{lll}0 & 8 & 0\end{array}$ & 1.3425 & 1 & 040 & 1.3425 & 2 \\
\hline 31 & 741 & 1.3220 & 1 & 432 & 1.3220 & 2 & $\begin{array}{lll}0 & 82\end{array}$ & 1.3220 & 7 & 025 & 1.3220 & 3 \\
\hline 32 & 820 & 1.3024 & 1 & 530 & 1.3024 & 5 & 068 & 1.3024 & 2 & 034 & 1.3024 & 3 \\
\hline 33 & 653 & 1.2837 & 1 & 413 & 1.2837 & 1 & 159 & 1.2837 & 2 & 231 & 1.2837 & 1 \\
\hline 34 & 660 & 1.2657 & 1 & $\begin{array}{lll}6 & 0 & 0\end{array}$ & 1.2657 & 4 & 084 & 1.2657 & 5 & $\begin{array}{lll}0 & 0 & 6\end{array}$ & 1.2657 & 4 \\
\hline 35 & 750 & 1.2485 & 1 & $\begin{array}{lll}6 & 1 & 0\end{array}$ & 1.2485 & 3 & 1311 & 1.2485 & 3 & 125 & 1.2485 & 3 \\
\hline 36 & 662 & 1.2320 & 1 & $\begin{array}{lll}6 & 0 & 1\end{array}$ & 1.2320 & 2 & $\begin{array}{lll}0 & 2 & 12\end{array}$ & 1.2320 & 2 & $\begin{array}{llll}0 & 1 & 6\end{array}$ & 1.2320 & 4 \\
\hline 37 & 752 & 1.2161 & 1 & $\begin{array}{lll}6 & 1 & 1\end{array}$ & 1.2161 & 1 & 177 & 1.2161 & 3 & $\begin{array}{lll}3 & 1 & 1\end{array}$ & 1.2161 & 1 \\
\hline 38 & 840 & 1.2008 & 1 & 620 & 1.2008 & 3 & 404 & 1.2008 & 1 & 106 & 1.2008 & 4 \\
\hline 39 & 910 & 1.1860 & 1 & 540 & 1.1860 & 2 & 086 & 1.1860 & 3 & 043 & 1.1860 & 2 \\
\hline 40 & 842 & 1.1718 & 1 & $\begin{array}{lll}6 & 2 & 1\end{array}$ & 1.1718 & 3 & 282 & 1.1718 & 3 & 116 & 1.1718 & 2 \\
\hline
\end{tabular}

${ }^{\mathrm{a}}$ Cell 1 (Cubic $\left.I\right): a=10.7400 \AA, V=1238.83 \AA^{3}$.

${ }^{\mathrm{b}}$ Cell 2 (Tetragonal $P$ ): $a=7.5943 \AA, c=5.3700 \AA, V=309.71 \AA^{3}$.

${ }^{\mathrm{c}}$ Cell 3 (Orthorhombic $F$ ): $a=5.0629 \AA, b=10.7400 \AA, c=15.1887 \AA, V=825.89 \AA^{3}$.

${ }^{\mathrm{d}}$ Cell 4 (Orthorhombic $P$ ): $a=3.7972 \AA, b=5.3700 \AA, c=7.5943 \AA, V=154.86 \AA^{3}$.

${ }^{\mathrm{e}}$ Number of lines calculated (NBS*AIDS83 [15]) with the specified $d$-spacing value. 
Table 4. Quaternary lattice metric singularity. The $d$-spacings for each lattice were calculated ${ }^{\mathrm{a}}$ using the specified $2 \theta$ maximum values and $\lambda=1.5405 \AA$. The number of unique $d$-spacings for the three lattices is identical. The low values for the compression ratios for lattices II, III, \& IV show that they are specialized (i.e. many $d$-spacings have the same value).

\begin{tabular}{|c|c|c|c|c|}
\hline & $\begin{array}{c}2 \theta \\
\text { Maximum }\end{array}$ & $\begin{array}{l}\text { Unique } \\
d \text {-spacings }\end{array}$ & $\begin{array}{c}\text { Total } \\
d \text {-spacings }\end{array}$ & $\begin{array}{c}\text { Compression } \\
\text { Ratio }^{b}\end{array}$ \\
\hline & 80 & 38 & 38 & 1 \\
\hline Cell $1^{\mathrm{c}}$ & 90 & 45 & 45 & 1 \\
\hline \multirow[t]{4}{*}{ Lattice I } & 100 & 53 & 53 & 1 \\
\hline & 110 & 60 & 60 & 1 \\
\hline & 120 & 67 & 67 & 1 \\
\hline & 80 & 38 & 76 & 0.500 \\
\hline Cell $2^{\mathrm{d}}$ & 90 & 45 & 92 & 0.489 \\
\hline \multirow[t]{4}{*}{ Lattice II } & 100 & 53 & 116 & 0.457 \\
\hline & 110 & 60 & 135 & 0.444 \\
\hline & 120 & 67 & 156 & 0.429 \\
\hline & 80 & 38 & 85 & 0.447 \\
\hline Cell $3^{\mathrm{e}}$ & 90 & 45 & 112 & 0.402 \\
\hline \multirow[t]{4}{*}{ Lattice III } & 100 & 53 & 140 & 0.379 \\
\hline & 110 & 60 & 167 & 0.359 \\
\hline & 120 & 67 & 191 & 0.351 \\
\hline & 80 & 38 & 77 & 0.494 \\
\hline Cell $3^{\mathrm{f}}$ & 90 & 45 & 95 & 0.474 \\
\hline \multirow[t]{3}{*}{ Lattice IV } & 100 & 53 & 120 & 0.442 \\
\hline & 110 & 60 & 138 & 0.435 \\
\hline & 120 & 67 & 165 & 0.406 \\
\hline
\end{tabular}

${ }^{\mathrm{a}}$ NBS*AIDS83 [15].

${ }^{\mathrm{b}}$ Compression ratio = "unique $d$-spacings/possible $d$-spacings" for a given symmetry.

${ }^{\mathrm{c}}$ Cell 1 (Cubic $I$ ): $a=10.7400 \AA, V=1238.83 \AA{ }^{3}$.

${ }^{\mathrm{d}}$ Cell 2 (Tetragonal $P$ ): $a=7.5943 \AA, c=5.3700 \AA, V=309.71 \AA^{3}$.

${ }^{\mathrm{e}}$ Cell 3 (Orthorhombic $F$ ): $a=5.0629 \AA, \quad b=10.7400 \AA, c=$ $15.1887 \AA, V=825.89 \AA^{3}$.

${ }^{\mathrm{f}}$ Cell 3 (Orthorhombic $P$ ): $a=3.7972 \AA, b=5.3700 \AA, c=7.5943$ $\AA, V=154.86 \AA^{3}$.

\subsection{Finding Potential Lattices}

As Mawsonite and Chatkalite demonstrate, the researcher needs to be aware of all possible lattices consistent with a given set $d$-spacings. In the case of Cubic $I$, one knows (Table 3 ) that at least 3 additional cells fit the data equally well. Single crystal studies [10] showed the lattice for Mawsonite is tetragonal $P$.

In other cases, the existence of further possibilities may not be known. To determine such possibilities, the DICVOL [1] indexing program has proved to be a valuable tool. In a recent publication [16] on the history of the dichotomy method for powder indexing, Boultif points out that the strategies used in DICVOL04 are appropriate for dealing with the above type of mathematical ambiguities. In the DICVOL04 approach, the "symmetries are scanned separately from the highest symmetry (cubic) towards the lowest symmetry (triclinic), while searching first for the solutions with smaller volumes." The case of Mawsonite and Chatkalite demonstrates that the correct solution is not necessarily the one with the higher crystal symmetry. Likewise for a given symmetry, the correct answer may not be the one with the smallest volume.

In any case, the researcher should always confirm the indexing solution with data from other techniques. This approach is the modus operandi for mineralogists. From the beginning Markham and Lawrence [7] were aware of a symmetry problem and used the phrase "body centered pseudo cubic" in the description of the new mineral. Even though they indexed Mawsonite on the basis of a Cubic $I$ cell, they noted the mineral cannot be truly cubic because of its anisotropic optical properties. The correct lattice was determined a decade later by means of single crystal data [10].

Finally, it is prudent to analyze the reduced form of a cell obtained via indexing procedures. Is there more specialization than required by the given reduced form type? As a specialized reduced form is frequently associated with a high compression ratio, it serves as an indicator of the existence of additional indexing possibilities.

\section{Conclusion}

The tetragonal $P$ lattice for the Mawsonite structure, as established by single crystal studies [10], is undoubtedly the correct lattice. As Chatkalite is presumed isostructural with Mawsonite, its powder data has been refined on the basis of a tetragonal unit cell [13]. In the 2004 version of Fleischer's Glossary of Mineral Species [14], both Mawsonite and Chatkalite are listed with tetragonal symmetry.

The historical confusion on the symmetry of Mawsonite has a valid mathematical explanation. The lattices for Mawsonite and Chatkalite are unusual because they are highly specialized. In each case: (1) the $a / c$ ratio is very near the square root of $2(\sqrt{ } 2=$ $1.4142, a / c$ for Chatkalite $=1.4163, a / c$ for Mawsonite $=1.4190) ;(2)$ the symmetrical scalars of the reduced form $[\boldsymbol{a} \cdot \boldsymbol{a}: \boldsymbol{b} \cdot \boldsymbol{b}: \boldsymbol{c} \cdot \boldsymbol{c}=1: 2: 2]$ have greater specialization than required for the given reduced form type; (3) the tetragonal lattice has derivative lattices of higher symmetry; and (4) the powder pattern is highly compressed (Table 4). 
Mawsonite is an exemplar-type structure. It crystallizes in a lattice that corresponds to the second member in the quaternary lattice metric singularity and not to the first with highest symmetry (Table 1). This result has important implications in structure analysis. First, any cubic $I$ lattice - established solely on the basis of indexing procedures - may actually be tetragonal or orthorhombic! Second, in determining the lattice of an unknown, results from powder data indexing procedures should routinely be confirmed by other techniques (e.g., single crystal, optical, etc.).

\section{References}

[1] A. Boultif and D. Louër, Indexing of powder diffraction patterns for low-symmetry lattices by the successive dichotomy method, J. Appl. Crystallogr. 24, 987-993 (1991).

[2] P.-E. Werner, L. Eriksson, and M. Westdahl, TREOR, a semiexhaustive trial-and-error powder indexing program for all symmetries, J. Appl. Crystallogr. 18, 367-370 (1985).

[3] A. D. Mighell and A. Santoro, Geometrical Ambiguities in the Indexing of Powder Patterns, J. Appl. Crystallogr. 8, 372-374 (1975).

[4] A. D. Mighell, Ambiguities in Powder Indexing: Conjunction of a Ternary and Binary Lattice Metric Singularity in the Cubic System, J. Res. Natl. Inst. Stand. Technol. 109, 569-579 (2004).

[5] A. D. Mighell, Lattice Symmetry and Identification-The Fundamental Role of Reduced Cells in Materials Characterization, J. Res. Natl. Inst. Stand. Technol. 106, 983995 (2001).

[6] V. L. Karen and A. D. Mighell, NIST*LATTICE-A Program to Analyze Lattice Relationships, Version of Spring 1991, NIST Technical Note 1290 (1991). National Institute of Standards and Technology, Gaithersburg, MD, 20899.

[7] N. L. Markham and L. J. Lawrence, Mawsonite, A New CopperIron-Tin Sulfide from Mt. Lyell, Tasmania and Tingha, New South Wales, American Mineralogist 50, 900-908 (1965).

[8] J. Ottemann, B. Nuber, and B. H. Geier, A Germanium and Zinc Bearing Variety of Mawsonite from the Tsumeb Deposit, Chem. Erde Bd 36, S, 110-117 (1977).

[9] T. Yamanaka and A. Kato, Mössbauer effect study of ${ }^{57} \mathrm{Fe}$ and ${ }^{119} \mathrm{Sn}$ in stannite, stannoidite, and mawsonite, American Mineralogist 61, 260-265(1976).

[10] J. T. Szymański, The Crystal Structure of Mawsonite, $\mathrm{Cu}_{6} \mathrm{Fe}_{2} \mathrm{SnS}_{8}$, Canadian Mineralogist 14, 529-535 (1976).

[11] S. A. Kissin and D. R. Owens, New Data on Stannite and Related Tin Sulfide Minerals, Canadian Mineralogist 17, 125135 (1979).

[12] H. T. Evans, Jr., D. E. Appleman, and D. S. Handwerker, Program and Abstract p42. Amer. Crystallogr. Assoc. Annual Meeting, Cambridge, Mass. (1963).

[13] V. A. Kovalenker, T. L. Evstigneeva, V. S. Malov, and L. N. Vyal'sov, Chatkalite, $\mathrm{Cu}_{6} \mathrm{FeSn}_{2} \mathrm{~S}_{8}$, a new mineral, Mineralog. Zhurnal. 3 (5), 79-86 (1981).

[14] J. A. Mandarino and M. E. Back, Fleischer's Glossary of Mineral Species 2004, The Mineralogical Record Inc., Tucson, Az. (2004).
[15] A. D. Mighell, C. R. Hubbard, and J. K. Stalick, NBS*AIDS80: A FORTRAN Program for Crystallographic Data Evaluation, National Bureau of Standards (U.S.), NBS Technical Note 1141 (1981). (NBS*AIDS83 is a development of NBS*AIDS80).

[16] A. Boultif, History of the dichotomy method for powder pattern indexing, Powder Diffraction 20 (4), 284-287 (2005).

About the author: Alan D. Mighell has been a research scientist at NIST since 1964. Currently, he is a Guest Researcher in the Data and Standards Group in the Ceramics Division. His research interests include structural crystallography and the design and development of mathematical procedures for materials identification, for establishing lattice relationships, and for the evaluation of crystallographic data. The National Institute of Standards and Technology is an agency of the Technology Administration, U.S. Department of Commerce. 